\title{
Benign Endobronchial Neoplasms: A Review
}

Abhishek Agarwal ${ }^{1}$, Abhinav Agrawal ${ }^{2}$, Sayee Sundar Alagusundarmoorthy ${ }^{2}$ and Nikhil Meena ${ }^{3 *}$

${ }^{1}$ Department of Medicine, Cooper University Hospital, Camden, New Jersey, USA

${ }^{2}$ Department of Medicine, Monmouth Medical Center, Long Branch, New Jersey, USA

${ }^{3}$ Department of Pulmonary and Critical Care Medicine, University of Arkansas for Medical Sciences, Little Rock, Arkansas, USA

\begin{abstract}
Benign endobronchial neoplasms are rare tumors of the tracheobronchial airways. These neoplasms are mostly slow growing and usual presentation is related to bronchial obstruction. Most patients present with symptoms such as, wheezing, cough, chest discomfort, hemoptysis or recurrent pneumonias. Radiographic findings may demonstrate, endobronchial lesions, atelectasis, pneumonia, bronchiectasis and in some instances even mediastinal shift. Imaging modalities are often non-specific. These lesions can lead to complications stemming from obstruction or asphyxiation, massive hemoptysis; requiring urgent surgical management. It is imperative to recognize their presence in a timely manner so that the appropriate intervention may be instituted. The reemergence of rigid bronchoscopy has bolstered the armamentarium of pulmonologists in diagnosis and management of such lesions. We review the clinical characteristics, diagnostic modalities and latest advancement in treatments and outcomes of benign endobronchial tumors.
\end{abstract}

Keywords: Endobronchial neoplasm; Benign; Airway obstruction

\section{Introduction}

Benign endobronchial neoplasms are rare tumors of the tracheobronchial airways. These neoplasms are mostly slow growing and usual presentation is related to bronchial obstruction. Most patients present with symptoms such as, wheezing, cough, chest discomfort, hemoptysis or recurrent pneumonias. Radiographic findings may demonstrate, endobronchial lesions, atelectasis, pneumonia, bronchiectasis and in some instances even mediastinal shift. Imaging modalities are often non-specific. These lesions can lead to complications stemming from obstruction or asphyxiation, massive hemoptysis; requiring urgent surgical management. It is imperative to recognize their presence in a timely manner so that the appropriate intervention may be instituted. The reemergence of rigid bronchoscopy has bolstered the armamentarium of pulmonologists in diagnosis and management of such lesions. We review the clinical characteristics, diagnostic modalities and latest advancement in treatments and outcomes of benign endobronchial tumors.

\section{Classification}

Benign endobronchial neoplasms are divided based on origin, into mesenchymal, submucosal glandular, and surface epithelial (papillomas) tumors [1]. The tumors of mesenchymal origin form the majority of these tumors, the most common being a hamartoma [2,3]. The classification of these neoplasms is listed in Table 1.

\section{Hamartomas}

Endobronchial Hamartomas (EH) are malformations caused by bronchial wall mesenchymal elements. They are the most common type of benign endobronchial neoplasms. Hamartomas occur more common in older males (ratio, 2-4:1) with the peak in the sixth decade [1]. It has been reported that factors like inflammatory lung disease and smoking contribute to a hamartoma [4]. Hamartomas contain a mixture of cartilage, bone, fat and smooth muscle tissues [5]. EH tend to have a higher content of fat than intraparenchymal lung hamartomas [6]. These EH are lined by respiratory epithelium. The ultrastructure of this epithelium contains a mixture of ciliated respiratory cells, clara cells, mucin secreting cells and type 2 pneumocytes. The stromal cells represent primitive mesenchymal cells and the cartilage demonstrates chondrocytes [1]. They usually to present with symptoms of bronchial obstruction like cough, wheezing, hemoptysis, dyspnea and fever [5].
Sequelae of endobronchial obstruction are easily evident on imaging; these include atelectasis, pneumonia and bronchiectasis. Sometimes the high fat content of the lesion is high enough to be evident on a computer tomography (CT) scan. Bronchoscopic examination shows a polypoid or pedunculated neoplasm, which is well circumscribed with a smooth and yellowish surface. The tumors do not involve the submucosa [7]. An endoscopic biopsy is essential for definite diagnosis.

\section{Our experience}

\section{Case 1: Symptomatic Patient with Airway Occlusion}

An 85-year-old African American male presented with shortness of breath to the emergency department. His Chest radiograph (CXR) showed left lower lobe (LLL) opacity. Patient was started on intravenous

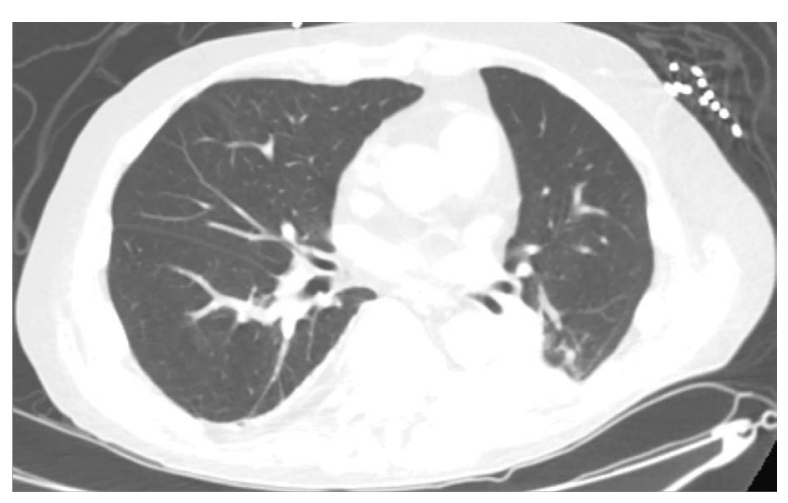

Figure 1: A sudden cutoff left lower lobe and distal atelectasis.

*Corresponding author: Nikhil Meena, University of Arkansas for Medical Sciences, 4301 W. Markham Mail Slot \#555, Little Rock, AR, USA, Tel: 501-686-5525; Fax: 501-686-7893; E-mail: nkmeena@uams.edu

Received May 01, 2015; Accepted July 15, 2015; Published July 20, 2015

Citation: Agarwal A, Agrawal A, Alagusundarmoorthy SS, Meena N (2015) (2015) Benign Endobronchial Neoplasms: A Review. J Pulm Respir Med 5: 275 doi:10.4172/2161-105X.1000275

Copyright: (c) 2015 Abhishek A, et al. This is an open-access article distributed under the terms of the Creative Commons Attribution License, which permits unrestricted use, distribution, and reproduction in any medium, provided the original author and source are credited. 
Citation: Agarwal A, Agrawal A, Alagusundarmoorthy SS, Meena N (2015) (2015) Benign Endobronchial Neoplasms: A Review. J Pulm Respir Med 5: 275. doi:10.4172/2161-105X.1000275

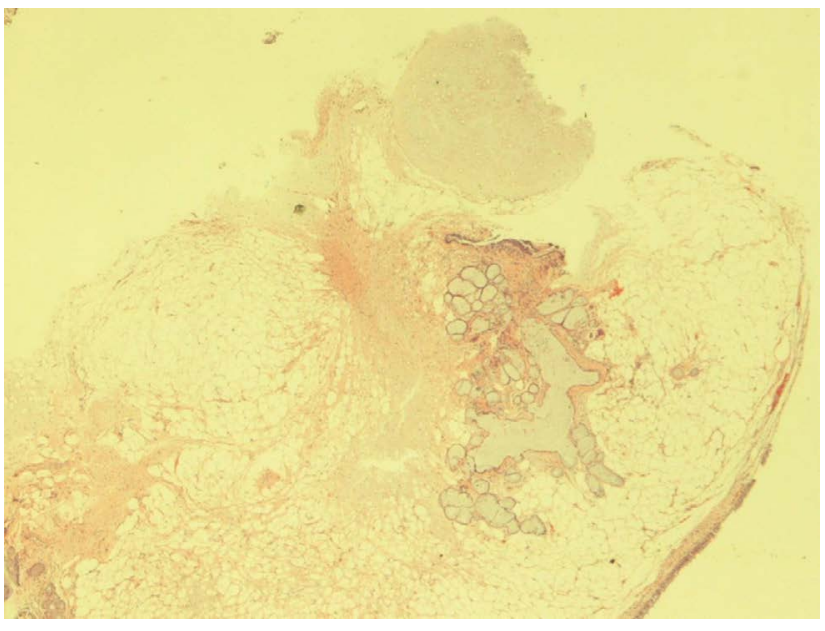

Figure 2: $5 \mathrm{~mm}$ well-circumscribed nodule composed of cartilage, adipose tissue, mucus glands and lined by ciliated respiratory epithelium. Consitent with endobronchial hamartoma. Which unlike peripheral hamartomas have mote adipose tissue.

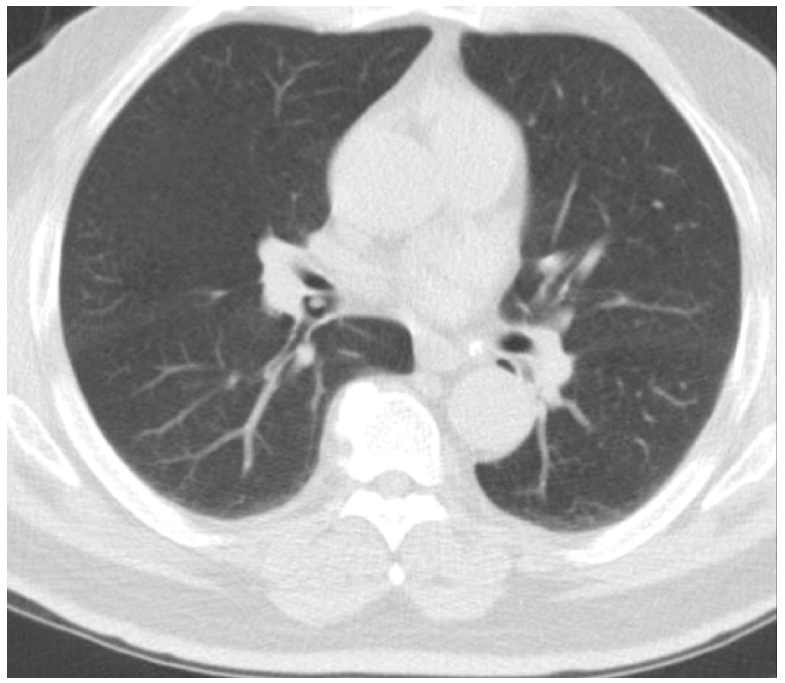

Figure 3: Possible pedunculated lesion in the distal right lung airway.

(IV) antibiotics to cover for possible health care associated pneumonia (HCAP). A CT chest done to evaluate he radiographic abnormality, demonstrated dense LLL atelectasis with a sudden cutoff at the lower lobe bronchus. (Figure 1) Patient underwent bronchoscopy that showed an endobronchial lesion with complete occlusion to the posterior subsegment of the lower lobe. This was removed in toto by biopsy forceps. Pathology showed mature sub-endobronchial adipose tissue, cartilage, and mucous glands, suggestive of hamartoma. (Figure 2) The patient later succumbed to sever sepsis stemming from ischemic colitis during the same admission.

\section{Case 2: Incidental Presentation}

A 63 y/o African American male had a low-dose lung cancer screening CT that demonstrated an endobronchial lesion at the take off at the distal bronchus intermedius (Figure 3). Flexible bronchoscopy confirmed the presence of the endobronchial lesion (Figure 4a), An

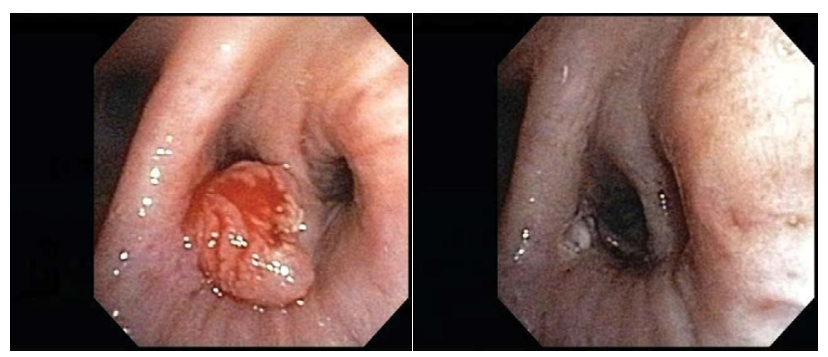

Figure 4: (a) Polypoid lesion in the distal bronchus intermedius, mid hemorrhage from a forcep biopsy, (b) the same lesion after snare electrocautery, base well cauterized.

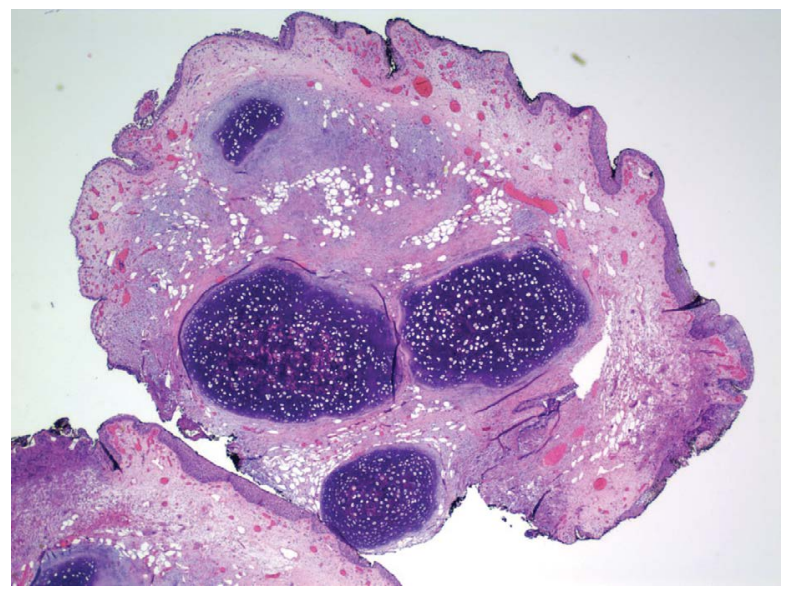

Figure 5: Lesion composed of cartilage and adipose tissue. Suggestive of endobronchial hamartoma.

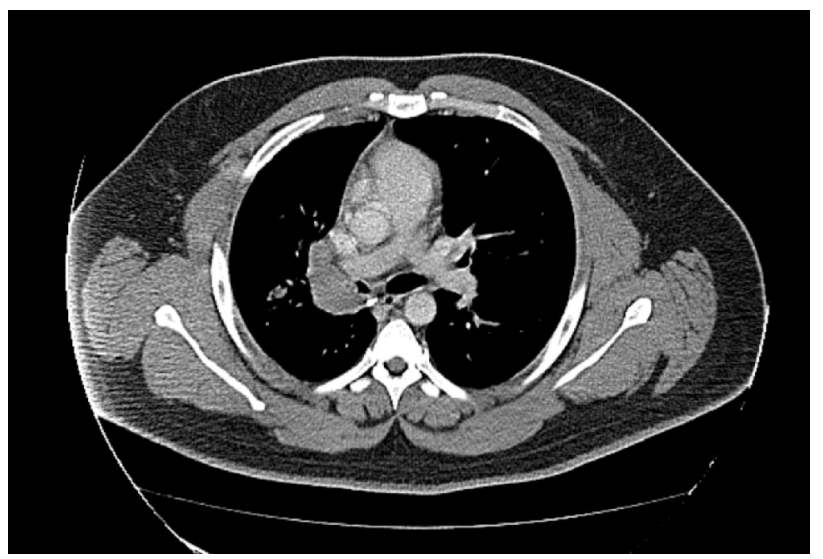

Figure 6: Large right hilar lesion with both parenchymal and endobronchial components.

electro-cautery snare was used to excise the nodule (Figure $4 \mathrm{~b}$ ). The pathology demonstrated findings suggestive of a hamartoma (Figure 5). The patient is stable and has no new endobronchial lesions at 12 months. 


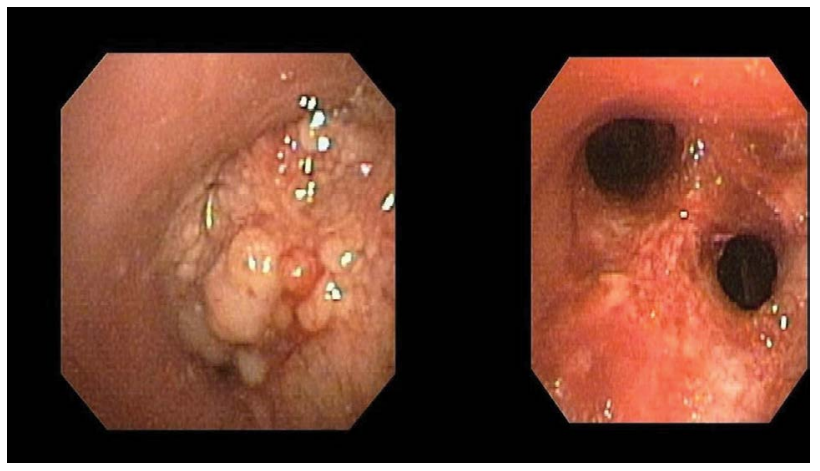

Figure 7: (a) right main bronchus almost completely occluded by an endobronchial lesion. (b) Right main bronchus reclaimed after tumor debulking

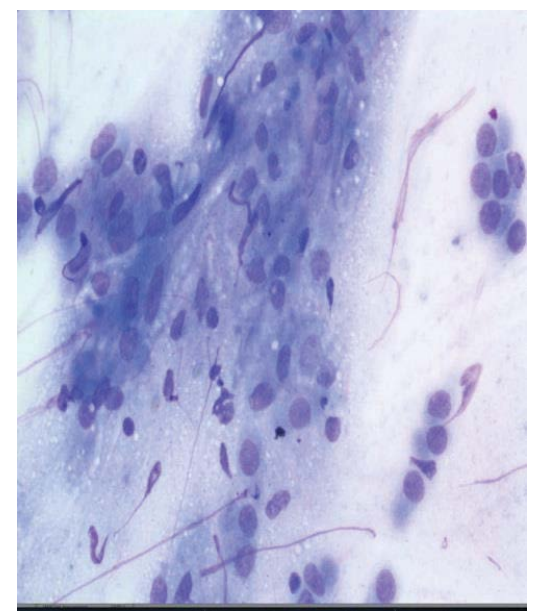

Figure 8a: Diff Quik stained slides show histiocyte-like cells forming syncytial aggregates. The tumor cells contain a granular cytoplasm and bland nuclei with inconspicuous nucleoli. (Diff Quik, 400x magnification)

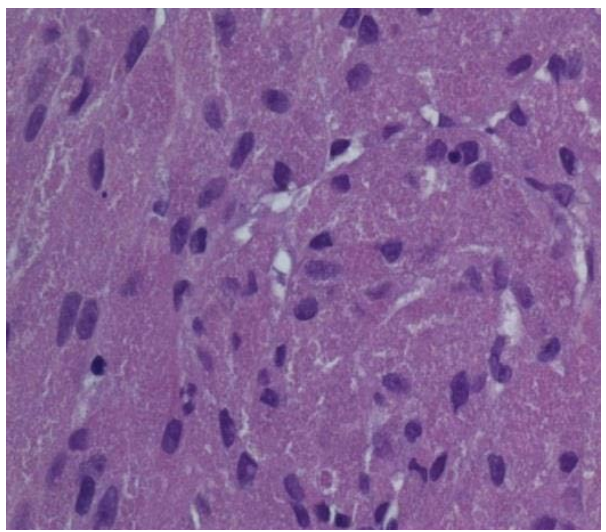

Figure $8 \mathrm{~b}$ : The biopsy shows a syncytium of cells with granular cytoplasm and bland nuclei. No cytologic atypia, mitoses or necrosis is present. (H\&E stain, $600 x$ magnification)

\section{Lipomas}

Endobronchial Lipoma (EL) is an extremely rare benign neoplasm

\begin{tabular}{|c|c|c|}
\hline $\begin{array}{l}\text { Tumors of Mesenchymal } \\
\text { Origin }\end{array}$ & $\begin{array}{l}\text { Tumors of Submucosal } \\
\text { Gland Origin }\end{array}$ & $\begin{array}{l}\text { Tumors of Surface } \\
\text { Epithelial Origin. }\end{array}$ \\
\hline $\begin{array}{ll}- & \text { Hamartomas } \\
- & \text { Lipomas } \\
- & \text { Chondromas } \\
- & \text { Primary } \\
\text { pulmonary leiomyomas } \\
- & \text { Granular cell } \\
\text { tumors } & \\
- & \text { Neurogenic } \\
\text { tumors } & \end{array}$ & $\begin{array}{lc}- & \text { Mucous } \\
\text { Gland Adenoma } & \\
- & \text { Pleomorphic } \\
\text { Adenoma } & \end{array}$ & $\begin{array}{l}\text { - Squamous } \\
\text { papillomas } \\
\text { a) Solitary } \\
\text { Papillomas } \\
\text { b) Recurrent Papillomas } \\
\text { papillomas Glandular cell } \\
\text { Papillomas Mixed } \\
\text { Pabroepithelial } \\
\text { polyps Fib }\end{array}$ \\
\hline
\end{tabular}

Table 1: Classification of Benign Endobronchial Tumors [1].

of the lung with an incidence reported to range from $0.1 \%$ to $0.5 \%$ of all lung tumors [8]. Most EL arise from the sub-mucosal layer of the bronchus. Smoking and obesity are considered risk factors for EL [9]. Occur more commonly in males and at any age [10]. Histologically, lipomas are mostly a composite of mature adipose tissue and blood vessels. Myxoid change and spindle cell foci along with other mesenchymal elements can be present sporadically [11]. The surface is lined with columnar respiratory or metaplastic squamous epithelium. Due to the insidious presentation these patients are frequently misdiagnosed and treated as asthma [12]. There have been no reports of malignant transformation of lipomas. A CT imaging the tumor is composed of adipose tissue and shows no enhancement with intravenous contrast [13]. On bronchoscopic examination, this neoplasm appears as a soft, white, yellow or grey pedunculated mass. These lesions are not vascular and can be sometimes wide based [13]. An endoscopic biopsy is essential for diagnosis. However, the existence of a fibrous, firm sheath around the tumor can prevent adequate tissue sampling in $50 \%$ of the cases [15].

\section{Chondromas}

Endobronchial Chondroma (EC) is also extremely rare. These tumors have historically been misclassified as hamartomas [16]. Although, they are more common in the trachea, they can be found anywhere in the airway [17]. More common in middle aged ( $3^{\text {rd }}$ to $5^{\text {th }}$ decades of life) males [18]. Histology shows lesions composed of cartilage and lack of entrapped epithelium. Bronchoscopy shows a pedunculated, vascularized, pink tumor with a lobulated gritty surface. Hamartomas and chondromas are considered to be on the spectrum of benign mesenchymal lung neoplasms.

\section{Primary Endobronchial Leiomyomas}

Primary Endobronchial Leiomyomas (EL) account for approximately $0.66 \%$ of all benign lung neoplasms [19]. They are thought to arise from the smooth muscles of the bronchial tree. Origin from the areas of cicatrical fibrosis has also been proposed. The mean age of patients with primary EL is thought to be 30-40 years and has equal incidence for either gender. Some literature reports female predominance, however this is could be due to the over reporting of benign metastasizing uterine leiomyomas [20]. Histologically, the spindle cells are arranged in intersecting fascicles and whorls with tapered cigar shaped nuclei with bland chromatin and cytoplasm. The ultrastructure is similar to uterine leiomyomas. It is thus essential to distinguish EL from benign metastasizing uterine leiomyomas and leiomyosarcomas in women. As it is difficult to diagnose EL on routine imaging, a bronchoscopy is used to visualize and biopsy the neoplasm.

\section{Endobronchial Granular Cell Tumors}

Endobronchial Granular Cell Tumors (EGCTs) are very rare 
benign pulmonary tumors. GCTs more commonly occur in skin and subcutaneous tissue, only 6-10\% cases occur in the lung [21]. Less than 80 cases of pulmonary GCTs have been described in the literature since the first case of EGCT was described in 1938 [22]. It usually occurs in middle-aged individuals but cases have reported in children as young as 5 years old [23]. There is no gender predilection. African Americans have a higher propensity to develop the tumor [24]. Smoking may be an inducing factor but causality has not been confirmed due to the small number of reported cases [25]. The origin of granular cell tumors has been in debate since it was first reported. Abrikossoff believed these tumors originated from the skeletal muscle as they were initially reported originating from tongue, lips and muscles of lower extremities [27]. Thus EGCT's were traditionally called 'granular cell myoblastoma'. However, based on the electron microscopy findings and cytochemical studies, EGCTs are now believed to originate from Schwann Cells (neural cell) [27]. EGCT is characterized by submucosal infiltrate of round to oval tumor cells with eosinophilic granular cytoplasm. Tumor cells can often infiltrate into peribronchial tissue. Squamous metaplasia of overlying epithelium can be seen along with subepithelial basement membrane thickening [28]. Immunohistochemistry analyses of the granules usually show positive staining for antibodies to S-100, vimentin, actin or neuron- specific enolase consistent with neural cell origin of the tumor. EGCT's vary in size from sub centimeter to more than $10 \mathrm{~cm}$, and the symptoms are dependent on the size. EGCTs have been shown to infiltrate locally producing cough and hemoptysis. If the tumor is big enough, it can cause bronchial obstruction and can lead to recurrent infections, dyspnea and chest pain. There has only been one reported case of malignant GCT [29]. On bronchoscopy GCTs usually appear as firm small isolated nodules or polyps with overlying normal mucosa. In obstructive cases, it can cause destruction of the pulmonary parenchyma distal to obstruction and could warrant a pneumonectomy. Most of them can usually be managed endoscopically.

\section{Our Experience}

A 35 y/o African American male presented to us with long standing asthma. His symptoms included loud wheezes, louder on the right. A CT scan demonstrated a right hilar mass obstructing the right main bronchus (Figure 6). A therapeutic bronchoscopy was performed; this confirmed as exophytic mass obstructing the right main bronchus (Figure 7a). After Rigid bronchoscope intubation, microdebrider and argon plasma coagulation were used for debulking (Figure $7 \mathrm{~b}$ ). The pathology demonstrated numerous syncytial clusters and single cells with coarse granular cytoplasm. Figure $8 \mathrm{a}$ and $\mathrm{b}$ show a syncytium of cells with granular cytoplasm and bland nuclei. No cytologic atypia, mitoses or necrosis were present (Diff quick, 400x and Hematoxylin and Eosin stain, 600x), this supports a diagnosis of granular cell cancer. The patient is doing well and has had no recurrence of tumor at 24 months after the ablation.

\section{Endobronchial Neurogenic Tumors/Schwannoma}

Neurogenic tumors usually arise in posterior mediastinum but can very rarely be seen in the bronchus primarily. Fewer than 50 cases have been described in the literature [30]. Most of the cases are either neurofibroma or schwannoma. Neurofibromas are neural in origin and usually associated with neurofibromatosis I, while schwannomas can arise sporadically [31]. Neuro-fibromas are complex tumors composed of axonal processes, Schwann cells, fibroblasts, perineurial cells, and mast cells [32]. Neurogenic tumors are characterized by interwoven sheets of fusiform of spindle cells with indistinct cytoplasm and palisading nuclei [33]. Immunohistochemistry demonstrates positivity for S-100 protein. Clinical features of neurogenic tumors are similar to other benign endobronchial tumors. It can cause obstructive symptoms when it enlarges. It can cause cough, chest pain, and dyspnea. Massive hemoptysis has been reported in the literature [34]. On bronchoscopy, benign neurogenic tumors appear firm, solid, encapsulated masses well demarcated from surrounding normal tissue. They can sometimes be cystic [33]. Complications can include massive hemoptysis leading to asphyxiation and death.

\section{Endobronchial Mucous Gland Adenoma}

Mucous gland adenomas are rare primary lung tumors. They comprise of less than $0.5 \%$ of all lung tumors. They are not associated with smoking and have a better prognosis than surface epithelial tumors [35]. Mucous gland adenomas arise from mucosal sero-mucous glands and ducts of trachea or bronchi [36]. The usual histologic findings include; acini lined by mucous secreting cells with a prominent cystic mucinous component. They are contained within the bronchus [37]. On immunohistochemistry, mucous gland adenomas are positive for high molecular weight keratins and negative for thyroid transcription factor-1 (TTF-1) [38]. Most of the patients with mucous gland adenomas are asymptomatic. Just like other endobronchial tumors, enlargement leads to obstructive symptoms. They can cause wheezing, atelectasis, infections, dyspnea and sometimes hemoptysis [35]. On bronchoscopy the tumor appears solitary, smooth and well circumscribed.

\section{Endobronchial Pleomorphic Adenoma}

Endobronchial Pleomorphic Adenoma (EPA) is also a rare primary endobronchial tumor. It accounts for $1 \%$ of all lung carcinomas [39]. It mostly occurs in the ages of 35 to 74 . EPA appears to originate from a mixture of luminal-type ductal epithelial and myoepithelial cells [40]. Histology shows sheets or trabeculae of myoepithelial and epithelial cells in myxoid matrix. Necrosis and high mitotic activity correlates with potential to turn malignant. Immunohistochemistry should reveal both epithelial and myoepitelial components with positivity to cytokeratine (CK) 5, CK7, CK14, CK 17, CK 18, vimentin and smooth muscle actin [41]. Like other endobronchial tumors, the symptoms depend on size. They can range from being asymptomatic to extensive post obstructive parenchymal destruction. Patients can present with dyspnea, cough, fevers or hemoptysis. There have been reports of EPA turning malignant [42]. On bronchoscopy these tumors appear to be usually solid, white, well demarcated and uncapsulated. Cut surface is myxoid, whitish, soft and rubbery [43].

\section{Squamous Papillomas}

\section{Solitary squamous papillomas}

Solitary squamous papillomas (SSP) are the most common solitary papillomas. Estimated incidence of SSP is 3.95 cases/100,000 patients/ year. The mean age of diagnosis is 54 . They are more common in men that smoke [44]. HPV infection has also been associated with squamous papillomas. They arise of squamous epithelial cells lining the respiratory tract. Histologically, they are characterized by keratinizing or nonkeratinizing mature squamous epithelium lining papillary connective tissue stalks [45]. On Bronchoscopy, they usually appear as exophytic, tan, friable masses with occasional ulceration. Patients with SSP can be asymptomatic at presentation or present with obstructive symptoms like cough, dyspnea, and hemoptysis.

\section{Recurrent respiratory squamous papillomas}

Recurrent Respiratory squamous papillomas (RRSP) are caused by HPV infection of stem cells in basal layers of respiratory mucosa. They have bimodal age distribution, occurring in children (Juvenile 
Onset RRRP) or occurring in adults around fourth decade of life (Adult Onset RRRP). Incidence of RRSP is around 4.3/100,000 children and $1.8 / 100,000$ adults. They have the same histologic features like SSP. RRRP most commonly affects larynx and can cause hoarseness, upper airway obstruction, choking sensation and sensation of something stuck in the throat. Although benign, RRP is difficult to control, has a high recurrence rate causes severe morbidity and have a higher risk for malignant transformation [46].

\section{Glandular Papillomas}

Glandular Papillomas are very rare group of papillomas with only 21 cases reported in English Literature since 1954 [47]. They arise from the mucosal surface of the central trachea-bronchial tree. On histology, they appear as papillary stromal cores lined by pseudostratified or single layer of ciliated or nonciliated columnar cells admixed with cuboidal cells or mucin-filled cells. Cellular atypia or necrosis is not seen [45]. They can appear as friable, red to tan in color tumors ranging in size from 0.7 to $2.5 \mathrm{~cm}$. Due to their endobronchial location, they can also cause obstructive symptoms like cough, dyspnea, recurrent infections or hemoptysis.

\section{Mixed Squamous and Glandular Cell Papillomas}

Mixed Papillomas occur predominantly in middle aged and older males. It has been associated with smoking. On histology, they show components of both squamous and glandular cell papillomas. Transitional urothelium-like morphology can be present between the two kinds of epithelium [48]. Immunological staining reveals positivity in all cells for CAM5.2, mucin MUC5AC, CK7, CK 19, CK5/6, TTF1 , indicating a common origin for different components of the tumor [1]. On bronchoscopy, they are hard to differentiate from squamous or glandular papilloma. Like other papillomas, they can cause obstructive symptoms. Recurrence has not been reported for mixed papillomas.

\section{Bronchial Fibroepithelial Polyp}

Bronchial Fibroepithelial Polyp (BEP) is an uncommon and poorly recognized endobronchial lesion, which has only been reported in literature as isolated case reports. The pathogenesis of these benign neoplasms has been attributed to chronic inflammatory etiologic factors. This includes chronic smoke inhalation, repeated airway infections, foreign body aspiration, prolonged mechanical ventilation and chronic inflammation in asthma and chronic obstructive pulmonary disease (COPD). Histologically, BEP consist of a fibrovascular core covered by normal respiratory epithelium [1]. BEP's are usually asymptomatic. When symptomatic, patients present with recurrent respiratory infections like pneumonias, refractory asthma, dyspnea or hemoptysis [49] While radiologic studies are usually ineffective in identifying the polyp, it highlight a possible inciting etiology, such as a foreign body or a broncholith. Lesions larger than $10 \mathrm{~mm}$ may also be visualized on CT scan. On bronchoscopy, the lesions appear as a firm nodule with a hard consistency and a whitish, glistening, smooth surface. While most patients exhibit good clinical course after resection, relapse has been reported in an isolated case report [50].

\section{Treatment and Outcomes}

We suggest following management approaches for a patient diagnosed with a benign endobronchial tumor.

Observation: This approach is reserved for asymptomatic patients and in whom the lesion more than likely to be benign based on the clinical context and radiographic findings. A trial of_steroids or antibiotics can be given if the lesions are thought to be secondary to a chronic inflammatory process. Trial of cytotoxic agents and antiviral agents may be done in case HPV is the suspected etiology of the lesion. This approach is especially suited to patients with multiple lesions, in whom debulking may not be practical.

Endoscopic intervention: With recent advancements in bronchoscopic techniques and instruments, this has become the first line of offence in management of endobronchial tumors. In patients with good overall status and minimal comorbidities flexible Bronchoscopy under local anesthesia is usually adequate. Rigid bronchoscopy under general anesthesia is preferred if procedure is anticipated to be prolonged (30 minutes or more) or poor cardio-pulmonary reserve is evident. Multiple debulking techniques including Nd: YAG laser, Argon plasma coagulation, electro cautery snare, ethanol injection and microwave solidification are available for use with or without a rigid bronchoscope [51]. The advantages and disadvantages of these techniques are summed in Table 2.

Our approach to endobronchial lesions includes, a diagnostic flexible bronchoscopy with or without endobronchial ultrasound for diagnosis and planning. If the lesion is small and pedunculated, we usually use an array of techniques (snares, forceps or needle knife) to excise the lesion during the first setting itself. For broad based, large or vascular, and loss of airway from tumor or bleeding is possible, the debulking procedures are performed through a rigid bronchoscope at a later date.

Surgical interventions: Indications for surgical intervention are, (a) histologic specimen cannot exclude malignancy from the differential, (b) significant bronchiectasis and/or organizing pneumonia post obstruction by the tumor, (c) tumor infiltration into bronchial wall or (d) there is airway distal to tumor obstruction (drowned and atelectatic lung) [52]. In pursuing this particular approach the use of tissue sparing

\begin{tabular}{|c|c|c|}
\hline Methods & Pros & Cons \\
\hline ND: YAG Laser & $\begin{array}{l}\text { 1) Higher heat can be delivered. } \\
\text { 2) Treatment of choice for } \\
\text { emergency airway maintenance. }\end{array}$ & $\begin{array}{l}\text { 1) Risk of airway fire when } \\
\text { used with high concentration } \\
\text { of oxygen precluding its use } \\
\text { 2) Cauterization of large } \\
\text { tumors can cause temporary } \\
\text { airway edema and stenosis } \\
\text { 3) Increased risk of } \\
\text { hemorrhage and airway } \\
\text { perforation. }\end{array}$ \\
\hline $\begin{array}{l}\text { Microwave } \\
\text { solidification }\end{array}$ & $\begin{array}{l}\text { 1) Weak cauterization power. } \\
\text { 2) Can be used with high } \\
\text { oxygen due to minimal smoke } \\
\text { production } \\
\text { 3) Can be used for tumors } \\
\text { located at acute angles }\end{array}$ & $\begin{array}{l}\text { 1) Weak cauterization power } \\
\text { precludes use in large } \\
\text { tumors }\end{array}$ \\
\hline $\begin{array}{l}\text { Argon Plasma } \\
\text { Coagulation }\end{array}$ & $\begin{array}{l}\text { 1) Decreased bleeding } \\
\text { 2) Decreased risk of wall } \\
\text { perforation } \\
\text { 3) Bends around corners }\end{array}$ & 1) Slow method \\
\hline $\begin{array}{l}\text { Electro-cautery } \\
\text { snare }\end{array}$ & $\begin{array}{l}\text { 1) Strong heating action can be } \\
\text { used for tumor solidification and } \\
\text { tumorectomy } \\
\text { 2) Treatment of choice for } \\
\text { obstructive tumors in poorly } \\
\text { vascularized areas } \\
\text { 3) Unlike other modes, No } \\
\text { histological change induced in } \\
\text { tumor specimen }\end{array}$ & $\begin{array}{l}\text { 1) Can cause deep heat } \\
\text { denaturation in the bronchial } \\
\text { wall } \\
\text { 2) Cannot be used for wide } \\
\text { based tumors }\end{array}$ \\
\hline Microdebrieder & $\begin{array}{l}\text { 1) Rapid debunking without heat } \\
\text { injury } \\
\text { 2) May not reach distal airways }\end{array}$ & $\begin{array}{l}\text { 1) Cannot be used on } \\
\text { vascular tumors } \\
\text { Can cause airway } \\
\text { injury rapidly }\end{array}$ \\
\hline
\end{tabular}

Table 2: Interventional techniques for benign endobronchial tumors [54-56]. 
Citation: Agarwal A, Agrawal A, Alagusundarmoorthy SS, Meena N (2015) (2015) Benign Endobronchial Neoplasms: A Review. J Pulm Respir Med 5: 275. doi:10.4172/2161-105X.1000275

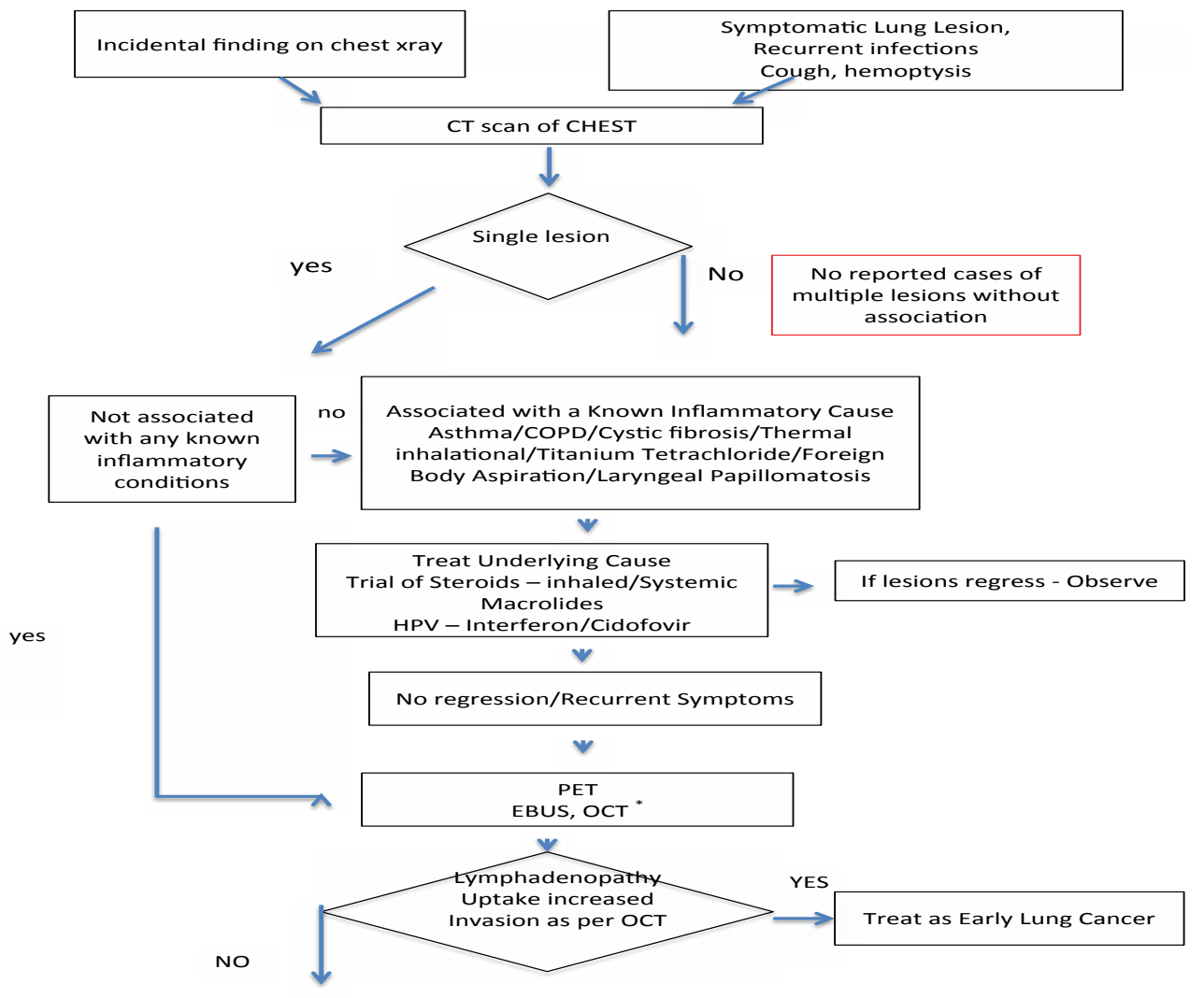

Figure 9: Outlines an algorithmic approach to patients with endobronchial lesions.

techniques must be accomplished with minimal parenchymal resection [53].

\section{References}

1. Wilson RW, Kirejczyk W (1997) Pathological and radiological correlation of endobronchial neoplasms: Part I, Benign tumors. Ann Diagn Pathol 1: 31-46.

2. Hurt R (1984) Benign tumours of the bronchus and trachea, 1951-1981. Ann R Coll Surg Engl 66: 22-26.

3. Arrigoni MG, Woolner LB, Bernatz PE, Miller WE, Fontana RS (1970) Benign tumors of the lung. A ten-year surgical experience. J Thorac Cardiovasc Surg 60: $589-599$

4. Gjevre JA, Myers JL, Prakash UB (1996) Pulmonary hamartomas. Mayo Clin Proc 71: $14-20$

5. Cosío BG, Villena V, Echave-Sustaeta J, de Miguel E, Alfaro J, et al. (2002) Endobronchial hamartoma. Chest 122: 202-205.

6. Gaerte SC, Meyer CA, Winer-Muram HT, Tarver RD, Conces DJ Jr (2002) Fatcontaining lesions of the chest. Radiographics 22 Spec No: S61-78.

7. Ahn JM, Im JG, Seo JW, Han HS, Yoon HK, et al. (1994) Endobronchial hamartoma: CT findings in three patients. AJR Am J Roentgenol 163: 49-50.

8. Altin S, Dalar L, Karasulu L, Cetinkaya E, Timur S, et al. (2007) Resection of giant endobronchial hamartoma by electrocautery and cryotherapy via flexible bronchoscopy. Tuberk Toraks 55: 390-394.

9. Schraufnagel DE, Morin JE, Wang NS (1979) Endobronchial lipoma. Chest 75 : 97-99.

10. Suzuki N, Takizawa H, Yamaguchi M, Matsuzaki G, Kiyosawa H, et al. (1992) [A case of asymptomatic endobronchial lipoma followed for 4 years]. Nihon Kyobu Shikkan Gakkai Zasshi 30: 1879-1883.
11. Muraoka M, Oka T, Akamine S, Nagayasu T, Iseki M, et al. (2003) Endobronchial lipoma: review of 64 cases reported in Japan. Chest 123: 293-296.

12. Tomashefski JF Jr (1982) Benign endobronchial mesenchymal tumors: their relationship to parenchymal pulmonary hamartomas. Am J Surg Pathol 6: 531 540.

13. Basoglu A, Celik B, Akdag AO, Sengul AT (2004) Endobronchial lipoma: a rare cause of bronchial occlusion. Interact Cardiovasc Thorac Surg 3: 263-264.

14. Huisman C, van Kralingen KW, Postmus PE, Sutedja TG (2000) Endobronchial lipoma: a series of three cases and the role of electrocautery. Respiration 67 689-692.

15. Ko JM, Jung JI, Park SH, Lee KY, Chung MH, et al. (2006) Benign tumors of the tracheobronchial tree: CT-pathologic correlation. AJR Am J Roentgenol 186: $1304-1313$

16. Destito C, Romagnoli A Carlucci I, Mercuri M, Vulpio C et al. (1995) [Endobronchial lipoma: endoscopic resection or surgical excision? Report of a case and review of the literature]. G Chir 16: 445-447.

17. Brewster DC, MacMillan IK, Edwards FR (1975) Chondroma of the trachea: report of a case and review of the literature. Ann Thorac Surg 19: 576-584.

18. Fernandez-Bussy S, Labarca G2, Descalzi F2, Pires Y2, Santos M2, et al. (2014) Endobronchial chondromas. Respir Care 59: e193-196.

19. Anrijs S, Weynand B, Pirson F, Rodenstein D, Pieters T (2009) Chondroma: an uncommon case of bronchial tumor. J Bronchology Interv Pulmonol 16: 270 273.

20. Mathur RM, Sen G, Yadav KS (1993) Endobronchial leiomyoma. Indian $J$ Cancer 30: 16-19.

21. Dmello D, Javed A, Espiritu J, Matuschak GM (2009) Endobronchial leiomyoma: case report and literature review. J Bronchology Interv Pulmonol 16: 49-51. 
22. Enzinger F, Weiss SW (1995) Benign tumors of peripheral nerves. In: Enzinger F, Weiss SW, editors. Soft tissue tumors. Mosby Co.

23. Yoon Y, Curry K (2005) Concurrence of granular cell tumor and Mycobacterium tuberculosis. South Med J 98: 1034-1035.

24. Sawada K, Fukuma S, Karasawa K, Suchi T (1981) Granular cell myoblastoma of the bronchus in a child: a case report. Jpn J Surg 11: 111-114.

25. McCarthy MJ, Rosado-de-Christenson ML (1995) Tumors of the trachea. J Thorac Imaging 10: 180-198.

26. van der Maten J, Blaauwgeers JL, Sutedja TG, Kwa HB, Postmus PE, et al (2003) Granular cell tumors of the tracheobronchial tree. J Thorac Cardiovasc Surg 126: 740-743.

27. Abrikossoff A (1926) Uber Myome, ausgehend von der quergestreiften willkurlichen Muskulatur. Virchows Arch A Pathol Anat Histol 260: 215-233.

28. Sobel HJ, Marquet E, Avrin E, Schwarz R (1971) Granular cell myoblastoma. An electron microscopic and cytochemical study illustrating the genesis of granules and aging of myoblastoma cells. Am J Pathol 65: 59-78.

29. Deavers M, Guinee D, Koss MN, Travis WD (1995) Granular cell tumors of the lung. Clinicopathologic study of 20 cases. Am J Surg Pathol 19: 627-635.

30. Jiang M, Anderson T, Nwogu C, Tan D (2003) Pulmonary malignant granular cell tumor. World J Surg Oncol 1: 22.

31. Tsukada H, Osada H, Kojima K, Yamate N (1998) Bronchial wall schwannoma removed by sleeve resection of the right stem bronchus without lung resection. J Cardiovasc Surg (Torino) 39: 511-513.

32. Strollo DC, Rosado-de-Christenson ML, Jett JR (1997) Primary mediastina tumors: part II. Tumors of the middle and posterior mediastinum. Chest 112 1344-1357.

33. Zhu Y, Ghosh P, Charnay P, Burns DK, Parada LF (2002) Neurofibromas in NF1: Schwann cell origin and role of tumor environment. Science 296: 920-922.

34. Chen SR, Chen MH, Ho DM, Lin FC, Chang SC (2003) Massive hemoptysis caused by endobronchial schwannoma in a patient with neurofibromatosis 2 . Am J Med Sci 325: 299-302.

35. Kwon JW, Goo JM, Seo JB, Seo JW, Im JG (1999) Mucous gland adenoma of the bronchus: CT findings in two patients. J Comput Assist Tomogr 23: 758-760.

36. England DM, Hochholzer L (1995) Truly benign "bronchial adenoma". Report of 10 cases of mucous gland adenoma with immunohistochemical and ultrastructural findings. Am J Surg Pathol 19: 887-899.

37. Edwards CW, Matthews HR (1981) Mucous gland adenoma of the bronchus. Thorax 36: 147-148.

38. Méjean-Lebreton F, Barnoud R, de la Roche E, Devouassoux-Shisheboran M (2006) [Benign salivary gland-type tumors of the bronchus: expression of high molecular weight cytokeratins]. Ann Pathol 26: 30-34

39. PAYNE WS, SCHIER J, WOOLNER LB (1965) MIXED TUMORS OF THE BRONCHUS (SALIVARY GLAND TYPE). J Thorac Cardiovasc Surg 49: 663668.

40. Shanmugaratnam K (1991) Histological typing of tumours of the upper respiratory tract and ear. In: International Histological Classification of Tumours. 2nd ed. Berlin, Germany: World Health Organization.
41. Gakidis I, Mihos PT2, Chatziantoniou C2, Stamatelopoulos A2, Eftychiadis C3, et al. (2013) A large neglected pleomorphic adenoma of the lung: Report of a rare case. Asian Cardiovasc Thorac Ann 22: 620-622.

42. Takeuchi E, Shimizu E, Sano N, Yamaguchi T, Yanagawa H, et al. (1998) A case of pleomorphic adenoma of the lung with multiple distant metastases-observations on its oncogene and tumor suppressor gene expression. Anticancer Res 18: 2015 -20

43. Ang KL, Dhannapuneni VR, Morgan WE, Soomro IN (2003) Primary pulmonary pleomorphic adenoma. An immunohistochemical study and review of the literature. Arch Pathol Lab Med 127: 621-622.

44. Tryfon S, Dramba V, Zoglopitis F, lakovidis D, Sakkas L, et al. (2012) Solitary papillomas of the lower airways: epidemiological, clinical, and therapeutic data during a 22-year period and review of the literature. J Thorac Oncol 7: 643-648.

45. Flieder DB, Koss MN, Nicholson A, Sesterhenn IA, Petras RE, et al. (1998) Solitary pulmonary papillomas in adults: a clinicopathologic and in situ hybridization study of 14 cases combined with 27 cases in the literature. Am J Surg Pathol 22: 1328-1342.

46. Derkay CS, Wiatrak B (2008) Recurrent respiratory papillomatosis: a review. Laryngoscope 118: 1236-1247.

47. Suzuki S, Goto T1, Emoto K, Hayashi Y (2014) Rapidly growing glandular papilloma associated with mucus production: a case report. World J Surg Oncol 12: 160

48. Lin D, Jiang Y, Wang J, Ding L, Xin F, et al. (2013) Pulmonary mixed squamous cell and glandular papilloma mimicking adenocarcinoma: a case study and literature review. J Thorac Dis 5: E129-132.

49. Casalini E, Cavazza A, Andreani A, Marchioni A, Montanari G, et al (2015) Bronchial fibroepithelial polyp: a clinico-radiologic, bronchoscopic, histopathologic and in-situ hybridization study of 15 cases of a poorlyrecognized lesion. Clin Respir J.

50. Li M, Zhang G, Peng A, Wang C (2013) Bronchial fibroepithelial polyp: a case report and review of the literature. Intern Med 52: 373-376.

51. Kajiwara N, Kakihana M, Usuda J, Ohira T, Kawate N, et al. (2011) Interventional management for benign airway tumors in relation to location, size, character and morphology. J Thorac Dis 3: 221-230.

52. Schnader J, Harrell J, Mathur P, Joseph C, Koduri J, et al. (2002) Clinical conference on management dilemmas: bronchiectasis and endobronchial polyps. Chest 121: 637-643.

53. Gamblin TC, Farmer LA, Dean RJ, Bradley RA, Dalton ML (2002) Trachea polyp. Ann Thorac Surg 73: 1286-1287.

54. Lee P, Kupeli E, Mehta AC (2002) Therapeutic bronchoscopy in lung cancer Laser therapy, electrocautery, brachytherapy, stents, and photodynamic therapy. Clin Chest Med 23: 241-256.

55. Kajiwara N, Kakihana M, Usuda J, Ohira T, Kawate N, et al. (2011) Interventional management for benign airway tumors in relation to location, size, character and morphology. J Thorac Dis 3: 221-230.

56. Rodrigues AJ, Coelho D, Dias Júnior SA, Jacomelli M, Scordamaglio PR, et al. (2011) Minimally invasive bronchoscopic resection of benign tumors of the bronchi. J Bras Pneumol 37: 796-800. 